\title{
Реабілітаційне обстеження пацієнтів після вогнепальних поранень кисті і передпліччя
}

\author{
УДК 615.825:616-001.45:617.576+617.574 \\ Н. О. Шестопал
}

Національний університет фізичного виховання і спорту України, Київ, Україна

Резюме. Мета. Розробити та охарактеризувати схему реабілітаційного обстеження осіб після вогнепальних поранень кисті і передпліччя. Методи. Теоретичні (аналіз та систематизація спеціалізованої науково-методичної літератури щодо використання реабілітаційного обстеження пацієнтів з травмами верхніх кінцівок); клінічні (аналіз медичних карток, опитування, огляд); інструментальні (на рівні аналізу функцій та структур організму: гоніометрія, мануальне тестування м'язів, антропометричні виміри сегменту кінцівки, модифікована вербальна шкала болю, шкала тривоги Гамільтона та шкала самооцінки депресії; на рівні активності: шкала функціональної незалежності FIM (Functional Independence Measure); на рівні участі: шкала DASH (The Disabilities of the Arm, Shoulder and Hand Score), опитувальник військового). Результати. Запропоновано схему реабілітаційного обстеження, яка включала спостереження, опитування, збір анамнезу, визначення рухових порушень і рівня якості життя та базувалася на доменах Міжнародної класифікації функціонування, обмежень життєдіяльності та здоров'я (МКФ), спрямованих на покращення показників якості життя, корекцію рухових розладів та повернення пацієнтів до попереднього рівня функціонування. Проведене первинне обстеження дозволило чітко сформулювати реабілітаційний діагноз, визначити категоріальний профіль пацієнтів для подальшого планування і розроблення алгоритму фізичної терапії осіб після вогнепального поранення верхньої кінцівки, спрямованого на поетапне вирішення довгота короткотривалих цілей реабілітаційного втручання у SMART форматі.

Ключові слова: реабілітаційне обстеження, вогнепальні поранення, фізична терапія, рухові порушення, якість життя.

\section{Rehabilitation examination of patients after gunshot wounds of the hand and forearm}

\section{N. O. Shestopal}

National University of Physical Education and Sport of Ukraine, Kyiv, Ukraine

Abstract. Objective. Develop and characterize a scheme of rehabilitation examination of patients after gunshot wounds of the hand and forearm. Methods. Theoretical (analysis and systematization of specialized scientific and methodological literature on the use of rehabilitation examination of patients with injuries of the upper extremities); clinical (analysis of medical records, surveys, examinations); instrumental (at the level of analysis of body functions and structures: goniometry, manual muscle testing, anthropometric measurements of the limb segment, modified verbal pain scale, Hamilton anxiety scale and self-assessment scale of depression; at the level of activity: functional independence scale FIM (Functional Independence Measure; at the level of participation: DASH scale (The Disabilities of the Arm, Shoulder and Hand Score), military questionnaire). Results. A rehabilitation examination scheme was proposed, which included: observation, survey, history taking, determination of motor disorders and quality of life, and was based on the domains of the International Classification of Functioning, Restriction of Life and Health (ICF), aimed at improving quality of life, motor correction disorders and return of patients to the previous level of functioning. The primary examination allowed clearly formulating the rehabilitation diagnosis, determining the categorical profile of patients for further planning and development of an algorithm for physical therapy of patients after gunshot wounds of the upper extremity aimed at phasing long-term and short-term goals of rehabilitation intervention in SMART.

Keywords: rehabilitation examination, firearms, physical therapy, motor disorders, quality of life. 
Постановка проблеми. Застосування сучасних видів зброї обумовлює тяжкість вогнепальних поранень, зокрема верхніх і нижніх кінцівок, частота ушкоджень яких становить 53-70\% у загальній структурі бойової хірургічної травми [3]. Поранення верхніх кінцівок, за даними різних авторів, становлять 25-30\% усіх бойових травм і $є$ однією з провідних причин тимчасової і стійкої втрати працездатності. Показано, що найбільша кількість несприятливих результатів лікування спостерігається у потерпілих з пораненнями верхніх кінцівок, ускладненими травмою магістральних судин, периферичних нервів зі значним руйнуванням і дефектом кісток та м'яких тканин. При цьому первинні дефекти кісткової тканини становлять 7,1\% усіх ускладнень травм верхніх кінцівок, з яких 79,3\% належать до десректів довгих кісток [2]. Тобто глибина ушкодження залежить від сили механічної дії, ії напрямку, характеристики снаряду, внаслідок дії якого відбувається поранення, та від локалізації самого поранення. Ушкодження судинно-нервових пучків при вогнепальних та мінно-вибухових травмах спостерігаються у $28 \%$ поранених. А саме: ушкодження артерії та кістки - $40 \%$, артерії та нерва - $20 \%$, ізольовані ушкодження артерій - $19 \%$, артерії та вени - $12 \%$, повне ушкодження судинно-нервового пучка (артерія, вена та нерв) $-7 \%$, ушкодження великих вен - $2 \%$ [3]. Таким чином, рухові порушення з ураженням рухових гілок нерва проявляються у вигляді розвитку контрактур, зниження сили, швидкої стомлюваності [18]. Також вогнепальні переломи часто ускладнюються зовнішньою або внутрішньою кровотечею, шоком, жировою емболією [10]. Отже, такі наслідки мінно-вибухових та вогнепальних травм повинні враховуватися як на етапах оперативного лікування бійців, так i при подальшому розробленні реабілітаційних заходів у цієї категорії пацієнтів засобами фрізичної терапії, яка розглядає не тільки стан органів i систем організму, а й функціональні можливості людини в її повсякденному житті [7].

Таким чином, після оперативних втручань, які обов'язкові при вогнепальних пораненнях, можлива тривала іммобілізація, внаслідок якої відбуваються структурні зміни і стійка контрактура, яка на початку свого розвитку завжди $\epsilon$ однопричинною, а потім стає поліпричинною [8]. Тобто застосування фрізичної терапії спрямовано на повернення пацієнта до звичного способу життя і відновлення функціональної рухливості кінцівок [15]. Відомо, що, за даними наукових розвідок, обстеження $\epsilon$ першою та невід'ємною частиною фрізичної терапії, при якому визначаються обсяг i величина рухових порушень [5, 20, 22]. А саме, в описі професійної діяльності спеціальності «фізичний терапевт» Міжнародної стандартної класифрікації професій ISCO-08 обстеження пацієнтів вказується як перша складова частина, що передує створенню та виконанню програми фрізичної терапії [17]. Також, за даними Американської асоціації фрізичних терапевтів (АРТА), виокремлюють такі фрункціональні компоненти клінічної діяльності фрізичних терапевтів: обстеження (examination), оцінювання (evaluation), діагностика порушень (diagnosis), прогнозування (prognosis), втручання (intervention) [11].

Наприклад, автори David C. Saidoff, Andrew L. McDonough розглянули ознаки та симптоми, які спостерігали і заміряли під час обстеження, починаючи з історії хвороби й опитування, спеціальних тестів, пальпації, аналізу і процесу прийняття рішень, для складання плану лікування пацієнтів з травмами верхньої кінцівки [13].

F. M. Kalternborn теж розробив спосіб обстеження і лікування суглобів. А саме, для пошуку дисфуннцій використовував послідовну схему діагностики, яка включала ортопедичні, мануальні, неврологічні тести і дозволяла розпізнати та диференціювати порушення в різних тканинах (м'язи, кістки, суглоби, нерви) [19]. Тобто існуючі схеми обстеження зосереджувалися тільки на порушенні структури / функції без урахування порушень на рівні активності/участі [12].

А от з позицій системного підходу, за даними А. О. Герцика, в обстеженні пацієнтів з травмами опорно-рухового апарату (ОРА) доцільно виокремити такі функціональні компоненти, як спостереження, опитування, тестування та вимірювання, аналіз зібраних результатів. Тобто фрізичний терапевт розв'язує одне 3 головних питань обстеження - локалізує структуру, яка спричиняє рухові порушення [4].

С. Грін використовувала в своїй роботі картку фрізично-реабілітаційного обстеження для пацієнтів з вогнепальними пораненнями нижніх кінцівок, яка відображає показники гоніометрії (активної, пасивної), мануально-м'язове тестування, а також результати функціональних проб і тестів [6].

О. Остроушко також кількісно оцінювала показники обстеження пацієнтів після вогнепального поранення у плечовому суглобі. Таким чином, методи дослідження було розподілено за трьома компонентами за Міжнародною класифікацією фрункціонування: фрункції тіла та структури, активність, участь [9].

О. В. Бісмак запропонував схему (алгоритм) реабілітаційного обстеження пацієнтів 3 комп- 
ресійно-ішемічними невропатіями верхньої кінцівки, яка включала: опитування, збір анамнезу, визначення рівня ушкодження, ступінь неврологічного дефріциту, рухові та чутливі порушення, м'язові гіпотрофії і атрофії, контрактуру суглобів та м'язів [1].

Проте аналіз літературних та Інтернет-джерел свідчить, що проблемі реабілітаційного обстеження при вогнепальних пораненнях, як частині фрізіотерапевтичного втручання з урахуванням принципів МКФ, приділяється мало уваги. Тому вивчення структури та змісту реабілітаційного обстеження $€$ актуальною проблемою.

Робота виконана згідно зі Зведеним планом НДР НУФВСУ в галузі фрізичної культури і спорту на 2016-2020 рр. за темою 4.8 «Організаційні та методичні особливості фрізичної реабілітації осіб з вогнепальними та мінно-вибуховими ураженнями» (номер держреєстрації 0116U001667).

Мета дослідження - розробити та охарактеризувати схему реабілітаційного обстеження в осіб після вогнепальних поранень кисті і передпліччя.

Методи дослідження: теоретичні, клінічні, інструментальні.

Результати дослідження та їх обговорення. Проведено обстеження 76 пацієнтів після вогнепальних поранень кисті і передпліччя віком від 18 до 52 років, середній вік - 33,8 \pm 6,7 року. Серед них: 29 \% (22 чол.) мали травми уламкового характеру, 42 \% (32 чол.) - роздроблений стан, $18 \%$ (14 чол.) - ушкодження нервів, $11 \%$ (8 чол.) - ушкодження сухожилків, 82,3 \% (63 чол.) - часткове ураження периферичних нервів, 17,7 \% (13 чол.) - повне ураження. В ході дослідження у $47 \%$ (36 чол.) пацієнтів були множинні травми, у $15 \%$ (11 чол.) травми мали ізольований характер, у 38 \% (29 чол.) поєднані травми. При цьому у 76 хворих були ушкоджені сегменти: кисть - у 27,6 \% (21 чол.), передпліччя - зап'ястковий суглоб - 48,7 \% (37 чол.), ліктьовий суглоб - 23,7 \% (18 чол.). Дослідження проводили на базі військового госпіталю м. Ірпінь у період з 2018 по 2020 р.
Усі учасники були інформовані про цілі, організацію, методи дослідження та надали згоду щодо участі у ньому. Дослідження було затверджено Інституційним комітетом 3 етики (№ 2/2017), проведено з дотриманням міжнародних принципів Гельсінкської декларації Світової медичної асоціації (World Medical Association, 2013) та відповідно до Закону України «Основи українського законодавства про охорону здоров'я» (Law of Ukraine, 1992) про етичні норми і правила проведення медичних досліджень за участю людини.

Спираючись на рекомендації МКФ (реабілітаційний цикл Rehab-Cycle) та результати наукових досліджень провідних фрахівців, ми розробили схему реабілітаційного обстеження пацієнтів після вогнепальних поранень кисті і передпліччя, яка базувалася на доменах МКФ, згідно з якими у центрі уваги знаходяться життєві обставини, а не самі люди, але з урахуванням потреб кожного окремого пацієнта [16].

Обстеження здійснювали з метою виявлення рухових та фрункціональних порушень пацієнта для визначення ступеня активності повсякденного життя та можливості виконувати свої професійні обов'язки, впливу чинників отримання поранення й індивідуальних психофрізіологічних особливостей, за результатами яких встановлювали реабілітаційний діагноз з подальшим плануванням алгоритму втручання і контролем дієвості даного втручання.

Насамперед обстеження пацієнта після вогнепального поранення передпліччя та кисті складалося зі спостереження, суб'єктивного (опитування) оцінювання на рівні активності й участі та об'єктивного (тестування з використанням спеціальних шкал і замірів) на рівні структури і фрункції, на основі яких проводили аналіз та синтез результатів [5] (табл. 1).

Таким чином, спостереження здійснювали впродовж первинного обстеження та усього курсу реабілітації, в якому спостерігали спочатку неформально (не включено), не втручаючись, коли пацієнт не знав. Тобто звертали увагу на те, як

ТАБЛИЦЯ 1 - Схема обстеження осіб після поранення верхньої кінцівки

\begin{tabular}{|c|l|l|l|}
\hline № & \multicolumn{1}{|c|}{ Методи } & \multicolumn{1}{|c|}{ Мета } & \multicolumn{1}{|c|}{ Засоби } \\
\hline 1 & $\begin{array}{l}\text { Спостереження на рівні } \\
\text { активності та участі }\end{array}$ & $\begin{array}{l}\text { Візуально визначити рухові } \\
\text { порушення }\end{array}$ & Візуальне оцінювання, фотофіксація \\
\hline 2 & $\begin{array}{l}\text { Опитування на рівні активності } \\
\text { та участі }\end{array}$ & Скласти історію ураження & Запитання, бесіда \\
\hline 3 & $\begin{array}{l}\text { Тестування, вимірювання на } \\
\text { рівні структури і функцій }\end{array}$ & Описати рухові порушення & $\begin{array}{l}\text { Активні, пасивні рухи, використовуючи антропометрію, } \\
\text { гоніометрію, динамометрію, пальпацію, шкали, тести }\end{array}$ \\
\hline 4 & Аналіз зібраних даних & $\begin{array}{l}\text { Визначити обсяг рухових } \\
\text { порушень }\end{array}$ & Математично-статистичні \\
\hline
\end{tabular}


хворий заходив у кабінет, зачиняв двері, сідав на стілець, роздягався, тримав руку під час бесіди, та візуально оцінювали поставу, рухи пацієнта; коли він рухався невимушено, звертали увагу на симетрію і координацію рухів, компенсаторні дії, міміку, рівень самостійності, «мову тіла». А при формальному (включеному) спостереженні пацієнт знав про мету спостереження. При обстеженні суглобів використовували спочатку активні рухи, звертаючи увагу на чинники, що можуть обмежувати амплітуду рухів: біль, опір суглоба та спазм прилеглих м'язів [21]. Потім виконували пасивні рухи, беручи до уваги можливість пацієнта виконувати рухи повної амплітуди щодо всіх осей у променево-зап'ястковому та ліктьовому суглобах у всіх напрямках. Окрім того, рухи обома руками пацієнт виконував для оцінювання пропорцій м'язів, набряків, рубців, складок, які утворилися після оперативного втручання, а також фрункціональних можливостей постраждалої кінцівки і рівня больових відчуттів [19]. Пальпаторно визначали наявність болючості гіпертрофрічно змінених тканин і деформації суглобів для точної локалізації ушкодженої структури.

Під час опитування військових, створюючи атмосфреру довіри та співпраці, використовуючи біопсихосоціальний принцип МКФ, виявляли основні скарги та їх зв'язок з фрізичними навантаженнями, динаміку симптомів, попередній руховий статус, особливості професійної діяльності, чинники ризику. Також враховували думку пацієнта про ефективність попередніх реабілітаційних заходів, якщо такі були. Тому опитування дозволило з'ясувати першочергові завдання реабілітаційних втручань та потреби кожного військовослужбовця і його близького оточення. Таким чином, пацієнти брали активну участь у визначенні цілей, розуміючи мету фрізичної терапії. Також збирали анамнез супутніх ушкоджень та попередніх хірургічних втручань.

Особливу увагу звертали на характер болю, який описували за допомогою десятибальної візуальної аналогової шкали оцінки інтенсивності болю (VAS). У стані спокою всі пацієнти не відчували проявів болю, але під час навантаження 16 пацієнтів відчували невеликий біль, 38 - помірний, 22 - сильний. Повну відсутність болю не відзначив жоден пацієнт.

Спілкування з родичами військовослужбовців доповнювало психологічний портрет хворого, а також допомагало визначити актуальні потреби кожного бійця, який перебував у небезпечній бойовій обстановці й отримав психологічний стрес. Зокрема психосоматичний стан військовослужбовців визначали за шкалою тривоги Гамільтона та шкалою самооцінки депресії. Відповідно до результатів оцінювання показників анкети опитувальника PHQ-9 (Patient Health Questionnaire) шкали самооцінки депресії, яка більшою мірою віддзеркалює стан депресії у пацієнтів, що перебували в зоні бойових дій, найбільший бал «2» отримав показник «поганий настрій, пригніченість або відчуття безпорадності». Всі інші середні показники отримали 1 бал, що свідчить про наявність депресії помірного ступеня. За ступенем вираженості групи розподілили таким чином. Ознаки тривоги: в межах норми - 15 чол. (20\%), наявність тривоги - 24 чол. (32\%), із симптомами тривоги - 20 чол. (26\%), клінічно виражена тривога 17 чол. (22 \%); ознаки депресії: в межах норми 19 чол. (25\%), легкого ступеня - 28 чол. (37 \%), помірного ступеня - 16 чол. (21\%), вираженого ступеня - 13 чол. (17 \%). 3 важкою депресією не було виявлено жодного пацієнта.

Отже, завершальна частина обстеження об'єктивне оцінювання - полягала в послідовному виконанні тестів (гоніометрія, динамометрія, мануальне м'язове тестування). Наслідками вогнепальних уражень передпліччя та кисті у поєднанні 3 травмами периферичних нервів $€$ не тільки зменшення амплітуди рухів у суглобах, а й зниження м'язової сили пораненої руки. Тобто результати тесту свідчили, що у всіх хворих спостерігалося зниження м'язової сили ураженої кінцівки. Таким чином, аналіз отриманих результатів середніх показників сили пораненої правої руки становив 23,8 \pm 1,5 кг, лівої - 18,6 \pm 1,7 кг, що значно нижче від середніх показників сили здорової правої руки, яка становила 42,3 \pm 1,5 кг, і лівої - 32,8 \pm 1,6 кг. Також результати гоніометрії активної і пасивної амплітуди рухів у променево-зап'ястковому і променево-ліктьовому суглобах травмованої кінцівки були знижені, що засвідчило наявність артрогенної патології у пацієнтів, обмеження при виконанні рухів (згинання / розгинання, відведення/приведення). Зокрема, під час виконання тестів пацієнти інформували про наявність та динаміку симптомів (усно, мімікою). Також анкетування бійців за шкалами FIM і DASH для визначення якості життя пацієнта при первинному обстеженні виявило, що найчастіше на рівні активності вони мають такі проблеми: під час прийому їжі (користування столовими приборами), особистої гігієни (чищення зубів, прийняття душу), одягання, а також утруднена робота дрібної (застебнути та розстебнути ґудзики на сорочці, зашнурувати черевики) та крупної моторики (утримувати і перекладати предмет вагою більше 1 кг). Тобто найбільша частка групи обрала варіант «важко» - 36 чол. $(47,4$ \%), «помірно 
ТАБЛИЦЯ 2 - Категоріальний профіль осіб із вогнепальними пораненнями передпліччя та кисті на рівні активності й участі за МКФ

\begin{tabular}{|c|c|c|}
\hline $\begin{array}{l}\text { Обмеження пацієнтів на рівні } \\
\text { активності й участі }\end{array}$ & Методи обстеження & Значення за МКФ \\
\hline $\begin{array}{l}\text { Здатність проводити гігієнічні } \\
\text { процедури, одягатися }\end{array}$ & $\begin{array}{l}\text { Оцінка виконання } \\
\text { діяльності за шкалою } \\
\text { DASH }\end{array}$ & $\begin{array}{l}\text { d540.3 - тяжке обмеження (50-95 \%) здатності вдягатися } \\
\text { d5100.3 - тяжке обмеження (50-95 \%) } \\
\text { помірне обмеження у виконанні миття частин тіла }\end{array}$ \\
\hline $\begin{array}{l}\text { Здатність піднімати та } \\
\text { переносити об'єкти }\end{array}$ & $\begin{array}{l}\text { Оцінка виконання } \\
\text { діяльності за шкалою FIM }\end{array}$ & $\begin{array}{l}\text { d430.2 - помірне обмеження у здатності піднімати та переносити } \\
\text { об'єкти (25-49 \%) } \\
\text { d440.2 - помірне порушення у використанні точних рухів кистей }\end{array}$ \\
\hline $\begin{array}{l}\text { Відновлення професійних умінь } \\
\text { та навичок }\end{array}$ & Опитувальник військового & $\begin{array}{l}\text { d859.21 - неможливість реалізувати себе у професійній } \\
\text { діяльності (25-49 \%) }\end{array}$ \\
\hline
\end{tabular}

ТАБЛИЦЯ 3 - Категоріальний профіль осіб із вогнепальними пораненнями передпліччя та кисті на рівні структури і функції за МКФ

\begin{tabular}{|l|l|l|}
\hline \multicolumn{1}{|c|}{$\begin{array}{c}\text { Обмеження пацієнтів на рівні } \\
\text { структури та функцій }\end{array}$} & \multicolumn{1}{|c|}{$\begin{array}{c}\text { Методи } \\
\text { обстеження }\end{array}$} & 3начення за мкФ \\
\hline $\begin{array}{l}\text { Амплітуда активних та пасивних } \\
\text { рухів у суглобах верхньої кінцівки }\end{array}$ & Гоніометрія & $\begin{array}{l}\text { b7100.2 - помірні порушення рухливості ліктьового суглоба (25-49 \%) } \\
\text { b7202.1 - легкі порушення рухливості кісток передплесна (5-24 \%) }\end{array}$ \\
\hline Оцінювання тонусу м'язів & $\begin{array}{l}\text { Мануальне м'язове } \\
\text { тестування }\end{array}$ & $\begin{array}{l}\text { b7301.2 - помірні порушення (25-49 \%) сили м'язів однієї кінцівки } \\
\text { b7800.2 - помірні порушення м'язової скутості }\end{array}$ \\
\hline Оцінювання сили кисті & Динамометрія & $\begin{array}{l}\text { b7300.2 - помірні порушення сили кисті (25-49 \%) } \\
\text { b7401.2 - помірні порушення витривалості верхньої кінцівки (25-49 \%) }\end{array}$ \\
\hline Оцінювання рівня болю & Шкала болю ВАШ & b28016.3 - тяжкі порушення (50-95 \%) болю в суглобах \\
\hline
\end{tabular}

важко» - 3 чол. (3,9\%), «дуже важко» -32 чол. $(42,1 \%)$, «неможливо» - 5 чол. $(6,6 \%)$. Крім того, на рівні участі бійців хвилювали проблеми, пов'язані з їх професійною діяльністю: можливість одягати військове спорядження, утримувати зброю різного калібру, виконувати стрільбу, захисні дії. А саме: «неможливо» - 3 чол. $(3,9 \%)$, «дуже важко» - 26 чол. (34,2 \%), «важко» 29 чол. (38,2 \%), «помірно важко» - 18 чол. $(23,7 \%)$.

Об'єктивна інформація підкріплялася суб'єктивною, що допомогло в подальшому спільно співпрацювати з пацієнтом. Тобто проведене первинне обстеження свідчило про наявність розладів рухової та чутливої фрункцій ураженої кінцівки в осіб з даною патологією. Крім того, матеріали кожного етапу обстеження було оброблено математично-статистичними методами.

Отже, застосування компонентів МКФ, серед яких функціональні обмеження і порушення та ступінь їх прояву, психоемоційний статус пацієнта, ступінь його мотиваційної готовності до реабілітації та фрактори навколишнього середовища, надало змогу сформувати категоріальний профріль пацієнта після поранення передпліччя та кисті, який представлено у таблицях 2, 3.

\section{Клінічний випадок}

Пацієнт О., 1970 р. н. 12.01 .2019 р. поступив у військовий госпіталь м. Ірпінь зі скаргами на неможливість рухатися після ампутації обох стоп, болі в ділянці спини, тугорухливість право- го променево-зап'ясткового і ліктьового суглобів верхньої кінцівки, контузії голови після мінно-вибухового поранення, яке отримав чотири місяці тому. Відомо, що проведено хірургічне втручання на верхній кінцівці після відкритого перелому в ділянці правого передпліччя, також ампутацію нижніх кінцівок. Рекомендовано фрізичну реабілітацію верхньої кінцівки, протезування нижніх кінцівок.

При неформальному спостереженні пацієнту важко було рухати правою рукою при будь-якій зміні положення, а при формальному - неможливо обпиратися на праву кінцівку при поворотах тулуба. Також під час бесіди з пацієнтом з'ясувалося, що основні скарги, які його турбували на даний момент, - це неможливість сідати без допомоги рук, труднощі під час самообслуговування, які пригнічували стан пацієнта. Крім того, внаслідок контузії поганий слух на праве вухо ускладнював спілкування. Огляд історії хвороби надав інформацію щодо результатів хірургічного втручання. Було проведено МРТ обстеження.

Отже, результати обстеження відповідно до визначення МКФ показали: при первинному обстеженні пацієнт знаходився в положенні «лежачи» на ліжку з неможливістю перейти в положення «сидячи». Також на рівні активності/ участі визначили, що йому важко утримувати столові прибори правою рукою та під час прийому їжі, тому він частіше використовував ліву руку, 
зокрема чистив зуби лівою рукою. Сила правої руки при стисканні була ослаблена, тому прийом ліків відбувався лівою рукою, а права тільки підтримувала пляшечку з ліками.

На рівні структури/фрункції виявили, що показники периметра кисті i передпліччя правої кінцівки були більше норми у зв'язку з набряклістю кінцівки і наявністю післяопераційних рубців. А саме, за результатами антропометрії пораненої руки периметр кисті становив 21,4 см, а периметр передпліччя - 32,5 см. Тобто відзначалася значна тугорухливість у променевозап'ястковому та променево-ліктьовому суглобах правої кінцівки. Також гоніометрія показала: пасивне згинання в променево-зап'ястковому суглобі - 21,5 град., активне згинання в променевозап'ястковому суглобі - 19,5 град., пасивне розгинання в променево-зап'ястковому суглобі - 20,5 град., активне розгинання в променевозап'ястковому суглобі - 19,2 град., пасивне ульнарне відведення в променево-зап'ястковому суглобі - 18 град., активне ульнарне відведення в променево-зап'ястковому суглобі - 15,5 град., пасивне радіальне відведення в променевозап'ястковому суглобі - 7,5 град., активне радіальне відведення в променево-зап'ястковому суглобі - 4,8 град., пасивна пронація в променево-ліктьовому суглобі - 48 град., активна пронація в променево-ліктьовому суглобі - 45,8 град., пасивна супінація в променево-ліктьовому суглобі - 44,6 град., активна супінація в променеволіктьовому суглобі - 42,5 град., що означало ослаблення правої верхньої кінцівки на рівні важких порушень. Окрім того, м'язова сила правої кисті мала важкі порушення: сила пораненої правої руки - 24 кг, сила здорової лівої руки була більшою - 32,5 кг.

Таким чином, емоційний стан пацієнта був помірно порушений (за шкалою тривоги Гамільтона - 2 бали), а больовий синдром - помірний (за шкалою ВАШ - 5 балів з 10 можливих). Тому пацієнт мав труднощі при захопленні, утриманні та перенесенні предметів різного діаметра та ваги (за опитувальником військовослужбовця 4 бали). Також було важко одягати військове спорядження, а виконувати захисні дії - взагалі

\section{Література}

1. Бісмак ОВ. Реабілітаційне обстеження пацієнтів з компресійноішемічними невропатіями верхньої кінцівки [Rehabilitation examination of patients with compression-ischemic neuropathies of the upper extremity]. Слобожанський науково-спортивний вісник. 2019; 3(71): 72-6.

2. Бур'янов ОА, Страфун СС, Шлапак IП та ін. Вогнепальні поранення кінцівок [Gunshot injuries of limbs. Guidelines]. Методичні рекомендації. Київ, 2015. 46 с. неможливо. Крім того, вкрай важко було використовувати ушкоджену руку під час одягання та харчування (за шкалою FIM - 75 балів), тому очевидно фрізична активність була важко порушена (за шкалою DASH - 117 балів). Відомо, що пацієнт мав родину - дружину та 4 дітей - і до служби в армії працював охоронцем у приватній фрірмі.

Отже, у даного пацієнта за профрілем МКФ та біопсихосоціальної моделі реабілітації було встановлено провідні обмеження, виявлено ступінь порушень діяльності й участі та зниження якості життя і розладів фрункції ураженої кінцівки. Виявлені порушення враховували при розробленні реабілітаційного втручання для даного пацієнта, передусім для покращення його активності, участі та поліпшення функції верхньої кінцівки, включаючи умови і чинники, що впливали на ці обмеження. Визначали ефрективність заходів з їх усунення.

Висновки. Незважаючи на постійне удосконалення засобів діагностики та лікування, вогнепальні травми верхньої кінцівки $€$ однією з провідних причин тимчасової та стійкої втрати працездатності. Тому проведене первинне обстеження свідчило про зниження якості життя і неможливість виконувати свої профеесійні обов'язки. Також визначено наявність розладів рухової фрункції ураженої кінцівки в осіб з даною патологією. Відомо, що у науковій літературі не знайдено робіт, присвячених методичним розробкам обстеження осіб при вогнепальних ураженнях верхніх кінцівок на основі МКФ; також не знайдено відомостей про застосування у практиці вітчизняної реабілітації надійних інструментів оцінювання якості життя тематичного контингенту.

Перспективи подальших досліджень полягають в обгрунтуванні засобів фрізичної терапії при даній патології для створення ефективного моделювання алгоритму фрізичної терапії, яка дозволить пришвидшити функціональне відновлення і сприятиме підвищенню якості життя поранених.

Автор заявляє про відсутність консрлікту інтересів.

3. Вказівки з воєнно-польової хірургії [Questions from military-field surgery]; за ред. Заруцького ЯЛ, Шудрака АА; Військ.-мед. департамент МО України. Київ: Чалчинська НВ, 2014. 399 с.

4. Герцик АМ. Теоретико-методичні основи фізичної реабілітації/ фізичної терапії при порушеннях діяльності опорно-рухового апарату [Theoretical and methodological bases of physical rehabilitation/physical therapy in violation of the activity of the musculoskeletal system]: монографія. Львів: ЛДУФК, 2018. 220-1. 
5. Герцик АМ. Структура процедури обстеження опорно-рухового апарату у фізичній реабілітації [Structure of the procedure for examining the musculoskeletal system in physical rehabilitation]. В: Єрмаков СС, редактор. Педагогіка, психологія та мед.-біол. Проблеми фіз. виховання і спорту: зб. наук. пр. № 9. Харків, 2007. 23-5.

6. Грін С, Федоренко С. Характеристика стану рухової активності військовослужбовців із наслідками вогнепальних переломів кісток гомілки [Characteristics of the state of motor activity of servicemen with the consequences of firearms of the shin bones]. Молодіжний науковий вісник Східноєвропейського національного університету ім. Лесі Українки. 2018;(30):128-36.

7. Іващенко СН, Шахліна ЛЯ, Лазарєва ОБ. Особливості побудови фразової моделі фізичної реабілітації військовослужбовців, що постраждали внаслідок бойових дій [Features of constructing a phase model of physical rehabilitation of servicemen affected by hostilities]. В: Арзютов ГМ, редактор. Науковий часопис НПУ ім. М. П. Драгоманова: зб. наук пр. Вип. 3(72)16. Київ: НПУ ім. М. П. Драгоманова; 2016. 63-7.

8. Олекса АП. Ортопедія [Orthopedics]. Тернопіль: ТДМУ, 2006. 528 с.

9. Остроушко ОД. Обстеження функціональних можливостей опорно-рухового апарату для визначення ефективності реабілітаційних заходів при вогнепальних ураженнях плечового суглоба [Survey of functional capabilities musculoskeletal system to determine the effectiveness of rehabilitation Measures for gunshot lesions of the shoulder joint] / ОД Остроушко, ЮА Попадюха. Наук. часопис Нац. пед. ун-ту ім. М. П. Драгоманова. 2016. Вип. 3К1 (70). 135-8.

10. Страфун СС, Борзих НО, Курінний ІМ, Борзих ОВ. Клініко-організаційні аспекти при вогнепальних пошкодженнях верхніх кінцівок [Clinical and organizational aspects with firearms of upper extremities]. Травма. 2017;18(6): 64-8
11. A Guide to Physical Therapist Practice. Vol. 1, A Description of Parient Management. Physical Therapy. 1995 August; 75(8):764.

12. Cyriax J. Textbook of Orthopeadic Medicine: Diagnosis of Soft Tissue Lesions. 8th ed. London: Bailliere Tindall; 1982. 454 p.

13. David C. Saidoff, Andrew L. McDonough. Critical Pathways in Therapeutic Intervention: Upper Extremities. 2010. P. 368 http://prabhatbooks. blogspot.com/2010/0 ... eutic.html

14. International Standard Classification of Occupations: ISCO-08 International Labour Office [Internet]. Geneva: IL. O., 2012. Available from: http:// www.lo.org/public/english/bureau/stat/isco/docs/publication08.pdf

15. Hardy M, Woodall W. Therapeutic effects of heat, cold, and stretch on connective tissue. J Hand Therapy. 1998;(11):148-56.

16. International Classification of Functioning, Disability and Health (ICF) World Health Organization [Internet]. Available from: http://www.who.int/ classifications/icf/en/

17. International Standard Classification of Occupations: ISCO-08 International Labour Office [Internet]. Geneva: IL. O., 2012. Available from http:// www.ilo.org/public/english/bureau/stat/isco/docs/publication08.pdf

18. Jepsen JR, Laursen LH, Kreiner S. \& Larsen Al. Neurologica Examination of the Upper Limb: A Study of Construct 15. Validity, Open Neurol J, 3: 54-63. doi: 10.2174/1874205X00903010054

19. Kalternborn FM. Manual Mobilization of the Joints, Volum 1: The Extremities. 5th ed. Minneapolis: ORT. P, 1999. 287 p.

20. Magee D. Orthopedic Physical Assessment. 6th ed. London: Elsevier Health Sciences; 2013. 1294 p.

21. Maitland GD. Peripheral Manipulation, 3rd ed, London: ButterworthHeinemann; 1991

22. O'Sullivan SB, Schmitz TJ, Fulk GD. Physical rehabilitation. 6th ed. Philadelphia PA : F. A. Davis Company; 2014. 1505 p. 